\title{
STRATEGI MANAJEMEN PERPUSTAKAAN DALAM MENGHADAPI VANDALISME \\ (Studi Kasus Mengenai Strategi Manajemen Perpustakaan dalam Menghadapi Vandalisme oleh Pengguna di Perpustakaan Universitas Sumatera Utara)
}

\author{
Eka Efriza $^{1}$, Ninis Agustini ${ }^{2}$, Encang Saepudin ${ }^{3}$ \\ ${ }^{1}$ Universitas Islam Negri Sumatera Utara \\ ${ }^{2,3}$ Program Studi Ilmu Perpustakaan Universitas Padjadjaran \\ 1eka.evriza22@gmail.com, ${ }^{2}$ ninis.agustini@unpad.ac.id, ${ }^{3}$ encang.saepudin@unpad.ac.id
}

\begin{abstract}
The research was conducted to determine library management strategies in the face of vandalism, viewed from the aspects such as: human resources, budget, infrastructure and services. The research was conducted in the Library of Northern Sumatera University. The sample of the research amounted to 12 people. Respondents in this research were employees in the Library of Northern Sumatera University, including librarians. Research method used was the case study method with qualitative approach. Results of this study that in the aspects of human resources, USU library puts a number of employees and security officers (guards) at some point the library building which is prone to vandalism. From the aspect of the budget, USU Library allocates a budget for the maintenance and repair of the damaged collections. Then aspects of infrastructure, USU Library designing appropriate placement of infrastructure building a unique design that creates a spatial comfortable and safe for the user and is also equipped with a security system for library collections that include the use of security magnetic tape, CCTV, convex mirrors and magnetic detector. Meanwhile, judging from the aspect of services, the strategy pursued USU Library is providing various kinds of services to support the use of the collections by the user according to his needs, including standard collection services, circulation services, short loan collection service, maintenance services and collection services user guidance.
\end{abstract}

\section{Keywords: Library Strategies, Library} Management, Vandalism

ABSTRAK - Penelitian ini dilakukan untuk mengetahui strategi manajemen perpustakaan dalam menghadapi vandalisme dilihat dari aspek sumber daya manusia (SDM), anggaran, sarana prasarana dan layanan perpustakaan. Penelitian ini dilakukan di Perpustakaan Universitas
Sumatera Utara (USU) dengan jumlah informan sebanyak 12 orang. Informan dalam penelitian ini adalah para pegawai termasuk pustakawan di Perpustakaan USU. Metode penelitian yang digunakan adalah metode studi kasus dengan pendekatan kualitatif. Hasil penelitian ini bahwa dari aspek SDM, Perpustakaan USU menempatkan sejumlah pegawai dan petugas keamanan (satpam) di beberapa titik gedung perpustakaan yang rawan terjadi vandalisme. Dari aspek anggaran, Perpustakaan USU mengalokasikan sejumlah anggaran untuk perawatan dan perbaikan koleksi yang rusak. Kemudian aspek sarana prasarana, Perpustakaan USU merancang penempatan sarana prasarana sesuai desain gedung yang unik sehingga menciptakaan tata ruang yang nyaman dan aman bagi pengguna dan juga dilengkapi dengan sistem pengamanan untuk koleksi perpustakaan yang meliputi penggunaan pita magnetic, CCTV, cermin dan magnet detector. Sementara itu, dilihat dari aspek layanan, strategi yang dilakukan Perpustakaan USU adalah menyediakan berbagai jenis layanan untuk mendukung pemanfaatan koleksi perpustakaan oleh pengguna sesuai dengan kebutuhannya, meliputi layanan koleksi standar, layanan sirkulasi, layanan koleksi pinjam singkat (KPS), layanan perawatan koleksi dan layanan bimbingan pengguna.

Kata kunci: Strategi Perpustakaan, Manajemen Perpustakaan, Vandalisme

\section{PENDAHULUAN}

Vandalisme merupakan kerusakan atau penyalahgunaan koleksi perpustakaan yang disebabkan oleh perbuatan manusia. Di dalam Kamus Besar Bahasa Indonesia (2003, 1116), istilah vandalisme diartikan sebagai "perbuatan merusak dan menghancurkan hasil karya seni dan 
barang berharga lainnya (keindahan alam dsb)." Penyalahgunaan koleksi seperti memberi tanda tertentu, mencoret-coret yang tidak berarti, penyobekan dan pencurian dapat dimasukkan dalam perilaku vandalisme.

Menurut Fatmawati $(2007,6)$ ada delapan bentuk vandalisme yang terjadi di perpustakaan, yaitu:

a) pengeratan dan pembetotan halaman-halaman pada koleksi perpustakaan,

b) perobekan pada halaman tertentu,

c) pengguntingan pada gambar-gambar tertentu,

d) segala bentuk coret-coret tulisan atau penandaan yang menggunakan ballpoint, spidol, stabillo, maupun pensil warna,

e) pelipatan halaman tertentu pada buku,

f) pemanfaatan Kartu Anggota Perpustakaan (KAP) milik orang lain,

g) buku yang tidak dikembalikan melebihi batas tempo pengembalian, dan

h) penjiplakan/plagiat karya ilmiah (tugas akhirskripsi-tesis-disertasi).

Perpustakaan Universitas Sumatera Utara (USU) juga tidak terlepas dari bahaya vandalisme. Hal ini dapat dilihat dari banyaknya coretan, pelipatan halaman, hilangnya sejumlah halaman bahkan hilangnya koleksi. Tindakan perobekan, pemotongan, penghilangan artikel, ilustrasi dari majalah, buku, ensiklopedia dan lain-lain tanpa atau dengan menggunakan alat disebut mutilasi. Hal ini sesuai dengan yang dikatakan oleh Obiagwu (1992, 291) dalam artikelnya Library Abuse in Academic Institutions yaitu: "Mutilation is the excision of articles and illustration from journal, books, encyclopaedia, etc.”
Seseorang yang melakukan tindakan mutilasi pada buku karena satu alasan atau beberapa alasan lainnya disebut bibliocast. Seperti yang diungkapkan oleh Raabe (dalam Sasmita, 2007) bahwa, "Jika seseorang meminjam buku dari perpustakaan, kemudian membaca/melihat halaman menarik, kemudian tak tahan untuk memilikinya hingga merobek dan mengoyaknya, maka dia sudah jadi bibliocast atau sang penghancur buku." (Sasmita, 2007).

Di samping itu, tidak dipungkiri perilaku petugas perpustakaan sebagai penyebab kerusakan buku ketika menyusun buku kembali ke rak tidak sesuai dengan cara atau sistem yang telah ditentukan. Sumardji (1982, 14) mengatakan, "Pengecekan terhadap kebenahan simpanan dan susunan buku pada rak-rak perlu dilakukan terutama untuk mengecek apakah cara menyimpan dan menyusun buku pada rak telah sesuai dengan cara atau sistem yang telah ditentukan ataukah belum."

Hal tersebut sejalan dengan pendapat Martoatmodjo (1993, 46) yang mengatakan bahwa, "Petugas perpustakaan yang tidak memiliki rasa sayang kepada buku, dan tidak pernah belajar bagaimana cara memelihara dan merawat buku dapat membuat kesalahan fatal, sehingga menimbulkan kerusakan pada buku." Jadi, selain pengguna perpustakaan yang berpeluang dalam melakukan tindakan pengrusakan bahan pustaka, petugas perpustakaan juga memiliki andil yang cukup besar sebagai pelaku pengrusakan.

Di samping mutilasi buku, banyak juga ditemukan coretan pada halaman buku yang dilakukan oleh pengguna Perpustakaan USU. 
Azyumardi (2004, 164) menyebutkan bahwa terjadinya vandalisme khususnya pencoretan pada suatu koleksi perpustakaan dikarenakan:

Salah satu bagian fisik buku yang paling banyak mengundang interaksi pembacanya adalah margin, ruang kosong yang membingkai teks. Hal yang paling menyebalkan, tetapi juga paling mengasyikkan jika meminjam sebuah buku dari perpustakaan adalah menyaksikan jejakjejak pembaca sebelumnya di atas lembarlembar buku. Dari situ tampak bagaimana pendahulu kita berinteraksi, secara emosional maupun intelektual dengan isi buku. Seringkali proses linear mengikuti kalimatkalimat yang ditunjukkan dengan garis di bawah kalimat, dengan pensil atau tinta.

Selanjutnya, fakta di lapangan juga menunjukkan bahwa banyak pengguna Perpustakaan USU yang menggunakan Kartu Tanda Anggota (KTA) Perpustakaan USU milik orang lain saat meminjam buku di bagian sirkulasi. Alasan paling umum dikemukakan mahasiswa adalah karena kartu perpustakaannya tertinggal atau lupa dibawa sehingga mereka menggunakan kartu anggota perpustakaan milik temannya. Penggunaan kartu tanda anggota perpustakaan milik orang lain jelas merupakan pelanggaran terhadap peraturan perpustakaan. Peraturan perpustakaan merupakan pedoman bagi pengguna dalam memanfaatkan fasilitas dan layanan perpustakaan. Peraturan perpustakaan dimaksudkan untuk memelihara ketertiban di perpustakaan dan hendaknya dituangkan secara tertulis dalam bentuk surat keputusan pimpinan.
Peraturan yang tertulis biasanya dikomunikasikan dalam bentuk rambu-rambu, brosur, poster, dan lain-lain.

Bentuk vandalisme lainnya yang ditemui di lingkungan Perpustakaan USU adalah buku-buku yang tidak dikembalikan. Ini dapat dilihat dari daftar nama mahasiswa yang belum atau tidak mengembalikan buku perpustakaan yang dipajang di papan pengumuman Perpustakaan USU maupun di papan pengumuman program studi masing-masing. Daftar ini biasanya dipajang saat awal perkuliahan dimulai. Soeatminah $(1992,37)$ mengatakan bahwa, "Manusia yang tidak bertanggungjawab merupakan perusak yang paling hebat, karena tidak hanya menyebabkan kerusakan tetapi juga hilangnya bahan pustaka."

Terjadinya tindakan peminjaman dengan menggunakan kartu tanda anggota perpustakaan milik orang lain dan buku-buku yang tidak dikembalikan ke perpustakaan merupakan tanggung jawab dari staf bagian sirkulasi. Oleh karena itu, staf bagian sirkulasi harus memahami tugas dan perannya dalam menjalankan kegiatannya mengelola peminjaman dan pengembalian buku. Sulistyo-Basuki (1991, 257) mengatakan bahwa, "Bagian sirkulasi sebagai ujung tombak jasa perpustakaan karena bagian inilah yang pertama kali berhubungan dengan pemakai serta paling sering digunakan pemakai."

Penjiplakan atau plagiat karya ilmiah juga merupakan bagian dari bentuk vandalisme yang terjadi di lingkungan perpustakaan. Perpustakaan USU juga tidak terlepas dari ancaman penjiplakan atau plagiat karya ilmiah. Salah satu faktor yang memungkinkan terjadinya penjiplakan atau plagiat karya ilmiah ini adalah tersedianya akses ke 
berbagai karya ilmiah yang dihasilkan oleh sivitas akademika USU.

Salah satu faktor pendukung yang membuka peluang terjadinya vandalisme di perpustakaan adalah sistem layanan perpustakaan yang bersifat terbuka, di mana pengguna memiliki akses langsung terhadap koleksi perpustakaan. Kemudahan akses yang diberikan kepada pengguna untuk menemukan bahan pustaka yang relevan dan sesuai dengan kebutuhan informasinya melalui sistem layanan terbuka, juga dapat menjadi celah bagi pengguna yang tidak bertanggungjawab untuk melakukan penyalahgunaan koleksi perpustakaan seperti vandalisme. Sri Hartati (2007), mantan Kepala Perpustakaan UNY (periode 2002-2010), dalam kutipan wawancaranya di Harian Suara Merdeka mengatakan bahwa:

Perpustakaan yang menganut sistem layanan terbuka akan membuka peluang bagi pemakai untuk menyalahgunakan koleksi. Di sisi lain, sistem layanan terbuka perpustakaan memang akan memuaskan karena pemakai bebas memilih alternatif lain jika pustaka yang dicari tidak ada atau dengan kata lain dapat memilih pustaka yang isinya hampir sama dengan subjek yang diinginkan. Tingkat penyalahgunaan koleksi tergantung sampai sejauh mana pengelola mengantisipasi hal tersebut. (Harian Suara Merdeka, 2007).

Perpustakaan USU menyelenggarakan sistem layanan terbuka untuk penggunanya, artinya pengguna dapat mengambil langsung buku yang dibutuhkan dari rak buku. Sistem layanan terbuka ini dimaksudkan untuk memberi kebebasan kepada pengguna untuk memilih bahan pustaka yang diinginkan dan sangat bermanfaat untuk meningkatkan minat baca.

Sulistyo-Basuki (1991, 172) menyatakan bahwa: Manusia dalam hal ini pemakai perpustakaan dapat merupakan lawan atau juga kawan. Pemakai perpustakaan menjadi kawan bilamana dia membantu pengamanan buku dengan cara menggunakan bahan pustaka secara cermat dan hati-hati. Pengunjung akan menjadi musuh bilamana dia memperlakukan buku dengan kasar, sehingga sobek atau rusak.

Sementara itu, Dureau dan Clement (1990, 20), mengatakan bahwa: Kerusakan bahan pustaka oleh manusia ini disebabkan oleh pemakai perpustakaan maupun petugas perpustakaan itu sendiri. Pemakai perpustakaan kadang-kadang secara sengaja merobek atau mengambil bab tertentu dari buku, dan secara tidak sengaja mereka membuat lipatan tanda batas baca, atau membaca dengan melipat buku ke belakang yang mengakibatkan perekat buku dapat terlepas, sehingga lembaran-lembaran buku mudah lepas dari jilidannya.

Pendapat-pendapat di atas menegaskan bahwa manusia merupakan salah satu indikator yang harus menjadi perhatian perpustakaan sebagai penyebab kerusakan koleksi perpustakaan. Hal ini tentu menjadi hal yang serius bagi perpustakaan karena penggunaan bahan pustaka yang salah dan kebiasaan-kebiasaan buruk pengguna dalam memanfaatkan bahan pustaka, serta pengelolaan yang tidak sesuai prosedur dari petugas perpustakaan dalam memperlakukan bahan pustaka akan mengakibatkan perpustakaan kehilangan assetnya, baik dari segi kualitas informasinya maupun kuantitas koleksinya. 
Berdasarkan aturan hukum yang berlaku di Indonesia, sanksi pidana terhadap pelaku vandalisme diatur dalam Bab XXVII KUHP pasal 406-412 tentang "Penghancuran atau Perusakan Barang" dengan hukuman penjara selama 2 (dua) sampai 5 (lima) tahun dan/atau didenda senilai barang yang dirusak (Fatmawati, 2010, 72).

Dari uraian di atas, dapat dilihat bahwa Perpustakaan USU tidak terlepas dari bahaya vandalisme yang dapat mengakibatkan kerugian, baik bagi pihak Perpustakaan USU sendiri maupun kalangan civitas akademika sebagai pengguna dari layanan Perpustakaan USU. Oleh karena itu, penulis tertarik mengadakan penelitian ini untuk mengetahui lebih mendalam mengenai strategi manajemen perpustakaan USU dalam menghadapi tindakan vandalisme yang terjadi di lingkungan Perpustakaan USU.

Penelitian ini bertujuan untuk mengetahui strategi manajemen yang dilakukan perpustakaan USU dalam menghadapi tindakan vandalisme dilihat dari aspek sumber daya manusia, anggaran, sarana prasarana dan layanan yang disediakan.

Adapun manfaat yang diharapkan dari penelitian ini terbagi atas dua, yaitu:

1. Manfaat teoritis

Penelitian ini diharapkan dapat memberikan manfaat terhadap khasanah ilmu pengetahuan bidang ilmu perpustakaan dan informasi mengenai aspek pengembangan preservasi khususnya vandalisme yang dilakukan oleh pengguna di perpustakaan, serta memberikan kontribusi bagi penelitian lebih lanjut yang berhubungan dengan vandalisme di perpustakaan.

2. Manfaat Praktis
Hasil penelitian ini dapat digunakan sebagai alternatif masukan dan bahan pemikiran bagi Perpustakaan USU, instansi terkait serta pemerhati dunia perpustakaan dalam pengembangan perpustakaan khususnya tentang strategi manajemen perpustakaan dalam menghadapi vandalisme, sehingga perpustakaan dapat meminimalisir kerugian yang ditimbulkan akibat vandalisme.

\section{TINJAUAN PUSTAKA}

Suatu perpustakaan dapat dikatakan baik, apabila tingkat pemanfaatan koleksinya tinggi. Artinya semakin tinggi tingkat pemanfaatan koleksi maka semakin baik layanan perpustakaan tersebut. Sebaliknya, koleksi yang tidak digunakan berarti kurang dimanfaatkan bagi pengguna sehingga fungsi perpustakaan tidak tercapai. Pemanfaatan koleksi perpustakaan adalah proses, cara dan perbuatan memanfaatkan koleksi perpustakaan oleh pengguna untuk memenuhi kebutuhan informasinya. Hal ini dapat dilakukan dengan cara mendayagunakan sumber informasi yang terdapat di perpustakaan dan jasa informasi yang tersedia. Pada dasarnya pemanfaatan koleksi perpustakaan mencakup dua hal yaitu menggunakan koleksi dalam ruangan perpustakaan (in library use) dan meminjam koleksi dari bagian sirkulasi untuk digunakan di luar perpustakaan (out library use). Dalam memanfaatkan koleksi di perpustakaan, pengguna biasanya menggunakan cara-cara umum yang dapat dilihat dari kebiasaan mereka. Adapun cara memanfaatkan koleksi perpustakaan yang biasanya dilakukan oleh pengguna menurut Zulkarnaen (1997, 45) yaitu meminjam koleksi 
perpustakaan melalui layanan sirkulasi, membaca koleksi di tempat, mencatat informasi yang dibutuhkan dari koleksi, dan juga memanfaatkan jasa fotocopy untuk membuat duplikat atau salinan informasi yang diinginkan pengguna (Zulkarnaen, 2007).

Akan tetapi, tidak semua pengguna mengikuti aturan yang dibuat oleh perpustakaan perguruan tinggi dalam memanfaatkan koleksi untuk memenuhi kebutuhan informasinya. Masih banyak ditemukan tindakan penyalahgunaan dalam hal memanfaatkan koleksi perpustakaan yang dilakukan oleh pengguna. Penyalahgunaan koleksi perpustakaan ini termasuk dalam vandalisme. Vandalisme dalam bahasa yang sederhana berarti pengrusakan yang dilakukan oleh manusia. Sehingga secara harfiah, vandalisme di perpustakaan merupakan pengrusakan yang dilakukan oleh manusia, dalam hal ini adalah pengguna perpustakaan, terhadap koleksi dan fasilitas yang ada di perpustakaan.

Adapun bentuk tindakan perusakan yang dilakukan terhadap bahan pustaka yaitu: coretcoretan, menambah tulisan atau garis, memberi tanda dengan spidol atau pena warna, melipat halaman buku yang diinginkan, merobek, mengoyak halaman buku, menggunting gambar, mengambil atau menghilangkan beberapa bagian atau seluruh bagian buku, mematahkan punggung buku ketika membacanya, menggunakan buku sebagai pelindung saat hujan yang mengakibatkan buku menjadi basah, dan berbagai bentuk pengrusakan lainnya yang menyebabkan buku itu rusak serta pencurian terhadap koleksi perpustakaan.
Pelaku tindakan vandalisme di perpustakaan mengarah kepada pengguna perpustakaan itu sendiri. Kemungkinan pengguna perpustakaan sebagai pelaku vandalisme dikarenakan pengguna tidak memahami arti keberadaan sebuah perpustakaan, termasuk keberadaan koleksinya. Selain pengguna perpustakaan, tidak menutup kemungkinan pegawai sebagai pelaku vandalisme karena mengakibatkan kerusakan koleksi perpustakaan. Hal ini juga sejalan dengan yang dikatakan oleh Dureau dan Clement (1990, 20) bahwa kerusakan bahan pustaka yang disebabkan oleh faktor manusia dapat dilakukan oleh pemakai perpustakaan maupun petugas perpustakaan itu sendiri.

Vandalisme memang rentan terjadi di perpustakaan, tidak peduli dengan jenis perpustakaannya sekalipun itu adalah perpustakaan perguruan tinggi atau perpustakaan universitas seperti Perpustakaan USU. Ada banyak faktor yang melatarbelakangi terjadinya vandalisme dilihat dari sisi pengguna, sisi pegawai atau staf perpustakaan maupun sisi perpustakaannya sendiri. Adapun penyebab vandalisme dari sisi pengguna, antara lain: pengguna menginginkan koleksi asli (orisinil), koleksi tersebut susah didapatkan, pengguna tidak menyadari bahwa perbuatannya merusak koleksi itu salah, adanya keinginan untuk memiliki koleksi tersebut, kurangnya kesadaran pengguna dalam memanfaatkan koleksi perpustakaan, kurangnya rasa sayang terhadap koleksi perpustakaan, ketidakmampuan secara ekonomi untuk membeli buku, pelampiasan rasa tidak suka terhadap pegawai perpustakaan, malas meminjam buku dan memfotokopinya, serta adanya 
keinginan dan kesempatan untuk melakukan vandalisme.

Kalau dilihat dari sisi pegawai atau staf perpustakaan, maka penyebab terjadinya vandalisme di Perpustakaan USU, meliputi: pegawai yang tidak professional dalam menjalankan tugasnya, lemahnya pengawasan pegawai terhadap aktivitas pengguna di sekitar rak buku, kurangnya tanggung jawab pegawai dalam melaksanakan tugas di lapangan, sikap petugas perpustakaan yang tidak ramah dan perlakuan pegawai ketika menyusun buku kembali ke rak tidak hati-hati sehingga bisa mengakibatkan kerusakan sampulnya atau terlalu padat ketika menyusunnya juga bisa membuat buku itu rusak.

Di sisi lain, perpustakaan USU sendiri juga sangat berperan sebagai faktor pendorong terjadinya vandalisme, antara lain: lemahnya pengawasan perpustakaan terhadap koleksi, kurangnya jumlah koleksi, peraturan perpustakaan yang tidak tegas, sistem keamanan perpustakaan yang tidak maksimal dan tidak sesuai standar, kurangnya personel keamanan dan penempatan sarana prasarana yang salah tempat sehingga membuka kesempatan bagi mereka yang berniat melakukan tindakan vandalisme tersebut.

Rahayuningsih $(2007,2)$ mengatakan vandalisme dirasakan lebih banyak menghadirkan kerugian daripada keuntungannya.. Akibat tindakan vandalisme, koleksi perpustakaan menjadi berkurang sehingga dibutuhkan biaya yang tidak sedikit untuk memulihkan kembali kelengkapan koleksi perpustakaan. Oleh karena itu, pihak manajemen perpustakaan perlu melakukan strategi-strategi tertentu untuk melakukan pencegahan dan penanggulangan kerusakan koleksi akibat adanya tindakan vandalisme di perpustakaan. Upaya-upaya yang dilakukan untuk mengatasi vandalisme dapat diarahkan dari kesiapan manajemen perpustakaan mengelola sumber daya manusia, anggaran, sarana prasarana serta layanannya.

\section{METODE PENELITIAN}

Metode penelitian yang digunakan adalah metode penelitian kualitatif dengan pendekatan studi kasus berupa analisis terhadap strategi manajemen perpustakaan dalam menghadapi vandalisme di Perpustakaan USU.

\section{HASIL PENELITIAN}

\section{Aspek Sumber Daya Manusia}

Sejak awal sebuah perpustakaan didirikan, apapun jenisnya, mempunyai kegiatan utama mengumpulkan semua sumber informasi dalam berbagai bentuk, baik itu bentuk tercetak, bentuk elektronik, atau dalam bentuk lainnya untuk kemudian dikelola dan disusun menurut sistem yang digunakan agar tercapai tujuan yang diinginkan. Untuk mencapai tujuan tersebut, perpustakaan memerlukan langkah-langkah strategis, kebijakan yang aplikatif dan terencana secara konseptual serta tindakan yang konkret (Sutarno, 2006: 33).

Salah satu yang perlu dipersiapkan oleh sebuah perpustakaan adalah sumber daya manusia. Perpustakaan tidak dapat lepas dari peran sumber daya manusia (SDM) yang berada di dalamnya. Peran SDM di dalam sebuah perpustakaan sangat penting karena SDM yang melakukan seluruh kegiatan dalam rangka memenuhi tujuan perpustakaan. Perpustakaan 
tentunya membutuhkan perencanaan sumber daya manusia yang baik agar dapat menjalankan kegiatannya dengan efisien.

Perpustakaan USU memiliki SDM sebanyak 116 orang, terdiri dari 20 orang pegawai jabatan fungsional, 38 orang pegawai jabatan struktural dan 58 pegawai honor .Dari 116 orang pegawai yang dimiliki Perpustakaan USU, sebanyak 58 pegawai berlatar belakang ilmu perpustakaan, 15 orang di antaranya merupakan pegawai jabatan fungsional, 8 orang merupakan pegawai jabatan struktural dan sisanya 35 orang lainnya adalah pegawai honorer.

Jumlah SDM yang dimiliki Perpustakaan USU tidak sebanding dengan dengan jumlah pengunjung Perpustakaan USU. Sementara itu, jumlah anggota Perpustakaan USU yang harus dilayani sebanyak 45.420 orang (Tabel 1. Jumlah Anggota Perpustakaan Tahun 2013) dengan kunjungan pengguna ke Perpustakaan USU ratarata di atas 80.000 setiap tahunnya (Grafik 1. Jumlah Pengunjung Perpustakaan USU 20072013). Keadaan ini tentunya memaksa pihak manajemen Perpustakaan USU mengoptimalkan sumber daya manusia yang ada seefektif dan seefisien mungkin, karena tidak adanya penambahan pegawai di Perpustakaan USU.
Tabel 1. Jumlah Anggota Perpustakaan Tahun 2013

\begin{tabular}{|c|l|c|c||c|}
\hline No & Kategori & $\begin{array}{c}\text { Jumlah } \\
\text { Terdaft } \\
\text { ar }\end{array}$ & $\begin{array}{c}\text { Jumlah } \\
\text { Anggota } \\
\text { Perpustakaa } \\
\text { n }\end{array}$ & $\begin{array}{c}\text { Persen } \\
\text { tase }\end{array}$ \\
\hline 1 & Mahasiswa & 35.013 & 35.013 & $100 \%$ \\
\hline 2 & Dosen & 1.575 & 1.174 & $74,5 \%$ \\
\hline 3 & SPs & 9.233 & 9.233 & $100 \%$ \\
\hline \hline \multicolumn{2}{|c|}{ Jumlah } & $\mathbf{4 5 . 8 2 1}$ & $\mathbf{4 5 . 4 2 0}$ & $\mathbf{9 9 . 1 \%}$ \\
\hline
\end{tabular}

(Sumber: LAKIP Perpustakaan USU Tahun 2013)

Dengan jumlah pegawai yang tidak sebanding dengan jumlah pengguna atau anggota perpustakaan, tentunya butuh strategi khusus dalam hal penempatan pegawai di masing-masing titik pelayanan perpustakaan agar dapat menjangkau semua kegiatan yang ada di Perpustakaan USU. Dengan demikian, sebaran pegawai menjadi salah satu kunci dari pelayanan perpustakaan kepada pengguna. Oleh karena itu, ada pertimbangan-pertimbangan tertentu yang dipikirkan oleh pihak manajemen Perpustakaan USU dalam menempatkan pegawai di tiap titik pelayanan. Hal ini tentunya selain memaksimalkan kinerja di setiap unit layanan perpustakaan, juga sebagai bentuk antisipasi terhadap berbagai tindakan yang merugikan perpustakaan itu sendiri termasuk vandalisme. 


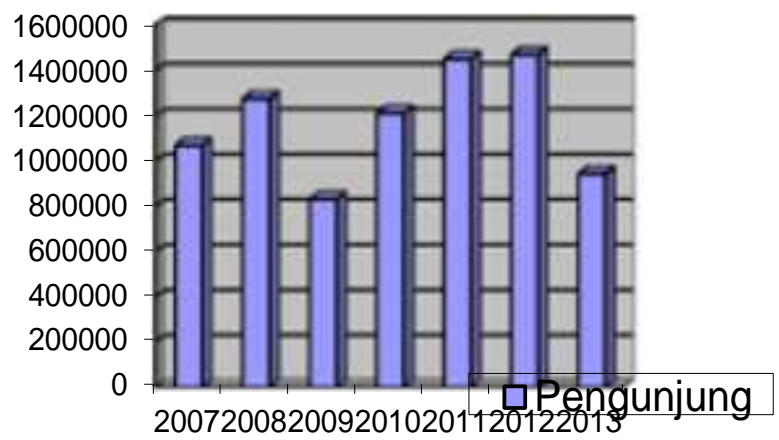

\section{Grafik 1. Jumlah Pengunjung Perpustakaan USU (2007-2013)}

(Sumber: LAKIP Perpustakaan USU Tahun 2013)

Di samping itu, untuk mengatasi kekurangan sumber daya manusia tersebut, pihak manajemen Perpustakaan USU membuka kesempatan magang dan Praktik Kerja Lapangan bagi mahasiswa Program Studi Ilmu Perpustakaan dan Informasi. Khusus untuk mahasiswa Program Studi Ilmu Perpustakaan dan Informasi USU, baik itu jenjang Diploma-3 maupun jenjang Strata-1, yang mengikuti mata kuliah Praktik Kerja Lapangan akan ditempatkan di Perpustakaan USU selama kurang lebih 3 bulan lamanya. Sementara untuk mahasiswa magang dan PKL di luar USU biasanya sekitar 1-2 bulan saja.

Penempatan posisi pegawai di masing-masing titik pelayanan menjadi bagian yang tidak dapat dipisahkan dari perencanaan manajemen perpustakaan. Seperti yang dikatakan oleh Sutarno (2006, 135) bahwa perencanaan adalah perhitungan dan penentuan tentang apa yang akan dijalankan dalam rangka mencapai tujuan tertentu.

Penempatan pegawai harus benar-benar disesuaikan dengan pendidikan, keahlian dan kemampuan pegawai menurut kebutuhan yang direncanakan sebelumnya. Penempatan pegawai yang salah dapat mengakibatkan manajemen kurang efektif dan kurang efisien. Di samping itu akan menimbulkan stress dan frustasi bagi pegawai yang bersangkutan karena mereka bekerja di bidang yang tidak sesuai dengan pendidikan, keinginan dan keahlian mereka.

Berdasarkan hasil penelitian, bahwa penempatan posisi pegawai untuk pekerjaanpekerjaan yang bersifat teknis seperti bibliografis dan katalogisasi yang membutuhkan keahlian khusus dipegang oleh pegawai yang berlatarbelakang pendidikan ilmu perpustakaan dan juga berstatus pustakawan. Sedangkan untuk pekerjaan-pekerjaan yang bersifat non-teknis yang tidak membutuhkan keahlian khusus seperti shelving dan sirkulasi, diberikan kepada pegawai yang bukan pustakawan dan tidak harus berlatar belakang ilmu perpustakaan, walaupun tidak tertutup kemungkinan bagi pegawai yang berstatus pustakawan dan berlatar belakang pendidikan ilmu perpustakaan untuk ikut merasakan pekerjaan-pekerjaan non-teknis tersebut.

Sebagaimana yang disampaikan oleh Daryono (2010) bahwa, "Keberhasilan layanan perpustakaan tergantung dari 3 faktor utama yaitu $5 \%$ bergantung dari fasilitas, $20 \%$ keberadaan koleksi, dan $75 \%$ staf perpustakaan/pustakawan." Vandalisme terjadi bukan hanya karena ada niat dari pengguna perpustakaan, akan tetapi juga karena adanya kesempatan. Oleh karena itu, pegawai perpustakaan dituntut untuk lebih waspada dan hati-hati dengan perilaku-perilaku 
vandalisme pengguna ketika berada di perpustakaan.

Tindakan-tindakan antisipasi seperti penempatan kamera pengawas/cctv, cermin besar di setiap sudut perpustakaan, kemudian juga penempatan detector di pintu keluar perpustakaan merupakan upaya pencegahan yang dilakukan perpustakaan agar pengguna berpikir ulang kalau ingin melakukan vandalisme di perpustakaan. Sementara itu, kalau koleksi perpustakaan ditemukan sudah dalam keadaan tidak bagus atau rusak, maka tindakan yang dilakukan adalah memperbaikinya agar informasinya dan wujudnya kembali utuh.

Di samping tindakan-tindakan antisipasi terhadap vandalisme yang dilakukan dalam bentuk teknis tersebut, bentuk antisipasi lainnya dapat dilakukan dengan menyiapkan SDM perpustakaan itu sendiri sebagai pemantau atau pengawas aktivitas pengguna di perpustakaan. Bukan hanya satpam (security) yang bertugas menjaga keamanan koleksi perpustakaan tapi juga pegawai atau staf yang bertugas di perpustakaan. Penempatan meja tugas atau kaunter pegawai di dalam sebuah gedung perpustakaan juga merupakan bagian dari upaya pengamanan koleksi perpustakaan dari tindakan vandalisme. Hal ini juga dimaksudkan untuk menutupi kekurangan yang ada pada area rekam cctv maupun cermin cembung karena jarak rekam pandangnya terbatas. Jadi, dari meja tugasnya, para pegawai juga dapat mengawasi aktivitas pengguna ketika berada di dalam gedung perpustakaan.

Keberadaan satuan pengamanan (satpam) atau security di lingkungan Perpustakaan USU juga merupakan bagian tak terpisahkan dari perencanaan SDM. Berdasarkan data yang dihimpun (Lampiran 1. Data Tata Usaha Perpustakaan USU), Perpustakaan USU memiliki 13 orang satpam yang bertugas di lingkungan Perpustakaan USU. Adapun penempatan posko tugas mereka yaitu 3 orang bertugas di dalam gedung utama lantai 2 Perpustakaan USU, 2 orang di lantai 1 gedung Perpustakaan USU, 2 orang bertugas di areal parkir timur Perpustakaan USU, 2 orang di areal parkir barat Perpustakaan USU dan sisanya 4 orang bertugas di areal parkir motor sebelah selatan gedung Perpustakaan USU.

Penempatan posko satpam dilakukan dengan berbagai pertimbangan termasuk pertimbangan keamanan koleksi perpustakaan agar terhindar dari aksi pencurian yang dilakukan mengingat desain gedung Perpustakaan USU yang unik dan memiliki banyak jendela yang terbuka tanpa terali besi sebagai pembatas. Kondisi jendela yang terbuka memang memungkinkan pengguna yang nakal untuk melakukan aksi pencurian dengan cara melemparkan buku perpustakaan melalui jendela tersebut. Dengan menempatkan satpam di beberapa tempat strategis di dalam maupun di luar gedung Perpustakaan USU sehingga kemungkinan pencurian bisa diminimalisir. Ketika aksi pencurian dilakukan dengan melemparkan buku melalui celah-celah jendela yang terbuka maka satpam akan melihatnya dari posko tugasnya sehingga bisa langsung dilakukan tindakan pengamanan terhadap koleksi perpustakaan tersebut.

Walaupun pegawai Perpustakaan USU tidak pernah ada yang mengikuti pelatihan khusus dalam menangani masalah vandalisme, setidaknya para pegawai sudah diberikan arahan tugas dari 
Kepala Bidang Perpustakaan USU, sebagaimana yang tercantum dalam uraian jabatan tugas masing-masing, yang bertujuan untuk menyelenggarakan pelayanan perpustakaan yang maksimal kepada pengguna dan mendukung visi misi Perpustakaan USU. Termasuk dalam penanganan vandalisme, sumber daya manusia atau SDM memiliki peran yang sangat penting dalam menghadapi dan mencegah terjadinya vandalisme di perpustakaan. Banyak hal yang dipertimbangkan oleh pihak manajemen ketika merekrut atau mengangkat seorang pegawai menjadi bagian dari SDM perpustakaan USU mulai dari sisi kualitas, karakteristik, kuantitas, penempatan posisi/jabatan dan rotasi, hingga penempatan meja tugas atau kaunter di dalam gedung perpustakaan. Semuanya diperhitungkan oleh manajemen Perpustakaan USU sehingga dapat memaksimalkan pelayanan kepada pengguna dan meminimalisir kerugian yang mungkin ditimbulkan akibat salah mengelola SDMnya. Salah satunya adalah meminimalisir kerugian yang mungkin ditimbulkan akibat tindakan vandalisme di perpustakaan.

Peningkatan kualitas sumber daya manusia di perpustakaan perlu dilakukan untuk memberikan pelayanan yang maksimal kepada pengguna. Pelayanan yang baik akan memberikan kepuasan kepada pengguna sehingga kecenderungan untuk melakukan pengrusakan atau vandalisme akan berkurang bahkan mungkin bisa hilang. Bila itu terjadi, tentunya perpustakaan tidak perlu lagi khawatir akan kehilangan asetnya dan citranya sebagai penyedia informasi bagi pengguna juga akan semakin baik. Di sisi lain, pengguna juga tidak lagi mengeluh ketika mendapatkan informasi yang dibutuhkannya tersedia di perpustakaan. Jadi, perencanaan SDM sangat dibutuhkan dalam manajemen perpustakaan. Tidak hanya untuk menjalankan tugas-tugas teknis maupun operasional, akan tetapi SDM juga diharapkan mampu untuk menciptakan kondisi yang nyaman dan bersahaja dalam melayani pengguna untuk memenuhi kebutuhan informasinya. Hal ini perlu dilakukan untuk mengatasi kemungkinan terjadinya vandalisme di perpustakaan yang disebabkan karena faktor kinerja pegawai yang tidak professional dan kondisi perpustakaan yang membuat pengguna tidak nyaman berada di dalamnya karena terlalu banyaknya aturan dan juga koleksinya yang tidak lengkap.

\section{Aspek Anggaran}

Di samping kesiapan SDM perpustakaan, aspek vital lainnya yang dibutuhkan oleh manajemen perpustakaan adalah kesiapan anggaran. Mustahil sebuah perpustakaan dapat menjalankan layanannya apabila tidak didukung dengan kesiapan anggaran untuk operasional semua kegiatan-kegiatan perpustakaan. Bryson (1990, 345) mengatakan kalau anggaran erat hubungannya dengan proses perencanaan lembaga, karena seluruh sumber daya dan kegiatan akan memerlukan anggaran untuk mencapai tujuan perpustakaan atau pusat informasi.

Berdasarkan Standar Nasional Perpustakaan SNP 010:2011 dijelaskan bahwasanya, Perguruan tinggi mengalokasikan anggaran perpustakaan setiap tahun sekurang-kurangnya 5\% dari total anggaran perguruan tinggi di luar pengembangan fisik, untuk pengembangan perpustakaan. 
Ketentuan tersebut tidak sepenuhnya dapat dilaksanakan oleh perpustakaan perguruan tinggi. Hal ini tergantung kebijakan yang dikeluarkan oleh pimpinan tertinggi perguruan tinggi atau universitas yang menaungi perpustakaan tersebut.

Perpustakaan USU mengalami penurunan jumlah anggaran yang cukup drastis beberapa tahun terakhir (kurun waktu 2010-2014). Adapun besaran anggaran yang kini disediakan untuk menunjang semua kegiatan yang dilakukan di Perpustakaan USU berkisar antara 3-4 miliar per tahunnya dengan pengalokasian anggaran maksimal 35\% untuk honorarium, 50\% untuk pengembangan koleksi dan sisanya $15 \%$ untuk pemeliharaan perpustakaan termasuk pemeliharaan koleksi dan semua peralatanperalatan yang ada di perpustakaan.

Terkait dengan kerusakan koleksi akibat vandalisme, di dalam perencanaan anggaran Perpustakaan USU memang tidak mengalokasikan dana khusus untuk menanganinya. Akan tetapi, anggarannya diambil dari $15 \%$ total anggaran yang disediakan untuk pemeliharaan perpustakaan, termasuk di dalamnya pemeliharaan koleksi dan semua peralatan-peralatan yang ada di perpustakaan.

Perpustakaan USU tidak terlalu mengkhawatirkan banyaknya anggaran yang akan dikeluarkan untuk memperbaiki koleksi yang rusak akibat vandalisme. Hal ini dikarenakan perpustakaan menganut filosofi 'kalau tidak ada kerusakan atau kehilangan buku di perpustakaan, berarti perpustakaan tersebut mati'. Perpustakaan USU memberikan kebebasan kepada penggunanya untuk memanfaatkan semua sumber daya informasi yang tersedia sehingga pengguna merasa nyaman dan 'welcome' dengan perpustakaan. Meskipun begitu di dalam kebebasan yang diberikan tersebut, ada pengawasan yang dilakukan oleh Perpustakaan USU, baik untuk keamanan koleksi perpustakaan maupun untuk kenyamanan pengguna itu sendiri.

\section{Aspek Sarana Prasarana}

Selain aspek sumber daya manusia dan anggaran, pertimbangan sisi sarana dan prasarana juga menjadi bagian yang penting untuk diperhatikan karena dalam pelaksanaan kegiatan perpustakaan diperlukan kenyamanan, keselamatan dan keamanan kerja. Gedung atau ruangan untuk sebuah perpustakaan mutlak perlu ada. Perpustakaan yang menempati gedung atau ruangan tersendiri, harus didesain dan ditata sedemikian rupa sehingga memenuhi persyaratan yang diperlukan dalam memberikan layanan dan suasana kerja yang memadai. Kemudian, di dalam gedung perpustakaan juga harus diperhatikan segala perlengkapan dan perabotan yang dibutuhkan di perpustakaan yang sering disebut sarana dan prasarana perpustakaan.

Perpustakaan USU memiliki gedung berlantai empat dengan luas sekitar $6.090 \mathrm{~m}^{2}$ yang terletak di tengah-tengah kampus. Setelah USU berubah status menjadi Perguruan Tinggi Badan Hukum Milik Negara (PT BHMN), Perpustakaan USU mulai mendekatkan pelayanannya kepada pengguna dengan membuka Perpustakaan Universitas Cabang pada sejumlah Fakultas. Gedung berlantai empat tersebut dibagi ke dalam beberapa ruangan, antara lain ruangan kerja pegawai, ruangan untuk koleksi dan pengguna, serta ruangan untuk keperluan lainnya seperti 
toilet, lift dan juga tangga . Di dalam gedung inilah, sarana dan prasarana pendukung ditata sedemikian rupa untuk menciptakan keserasian dalam penataan ruangnya.

Sarana dan prasarana perpustakaan adalah semua barang, perlengkapan dan perabot bahkan inventaris yang harus disediakan di perpustakaan (Sutarno, 2006: 83-84). Sarana dan prasarana perpustakaan harus memperhatikan model, tipe, mutu, ukuran, jumlah, jenis, warna, dan lain sebagainya. Hal ini penting agar semua barang dan benda tersebut dapat dipergunakan secara maksimal dan sesuai dengan kebutuhan perpustakaan. Adapun sarana dan prasarana yang digunakan di perpustakaan meliputi meja, kursi, rak bahan pustaka (buku, majalah, surat kabar, jurnal, dan koleksi pandang dengar), lemari katalog, meja sirkulasi, bangku, sofa, filing cabinet, troli, mesin (tik, komputer, fotocopy, jilid, scan, dll) lemari penitipan tas, papan pengumuman, telepon dan lain sebagainya. Untuk pengadaan sarana dan prasarana di perpustakaan, yang membuat kebijakannya adalah pihak manajemen, acuannya ada di Standar Nasional Perpustakaan.

Pada dasarnya kebutuhan ruang perpustakaan dialokasikan untuk koleksi, pemakai, staf, dan keperluan lainnya. Untuk itu perlu dipertimbangkan sistem layanan yang akan dianut oleh suatu perpustakaan, dengan sistem layanan terbuka (open access) atau sistem layanan tertutup (closed access). Selain itu, dalam perencanaan ruangan perlu dipertimbangkan keserasian dalam penataan ruang akan mempengaruhi produktivitas, efisiensi, efektivitas, dan kenyamanan pengguna (Lasa, 2005: 157).
Penataan sarana dan prasarana di Perpustakaan USU disesuaikan dengan desain gedung, luas ruangannya dan juga sistem layanan yang digunakan. Hal ini perlu dilakukan untuk menciptakan tata ruang yang apik dan juga enak dipandang mata. Perpustakaan USU menganut sistem layanan terbuka sehingga alokasi ruangannya dibagi menjadi tiga bagian, yaitu $70 \%$ untuk koleksi dan pengguna, 20\% untuk staf dan sisanya $10 \%$ untuk keperluan yang lain.

Seperti yang sudah disampaikan sebelumnya bahwa Perpustakaan USU menganut sistem layanan terbuka dalam penyelenggaraan pelayanannya kepada pengguna. Untuk mengantisipasi segala bentuk penyalahgunaan koleksi oleh pengguna dengan adanya sistem layanan terbuka ini, Perpustakaan USU merancang tata ruang yang sesuai dengan sarana dan prasarana yang tersedia. Dikarenakan bentuk gedungnya yang unik, maka Perpustakaan USU melakukan penyesuaian tata letak sarana dan prasarana pendukung terselenggaranya pelayanan yang optimal kepada masyarakat pengguna. Untuk koleksi-koleksi khusus seperti koleksi audiovisual, koleksi referensi, koleksi deposit, koleksi pembangunan, koleksi American Corner, dan koleksi langka ditempatkan di ruangan khusus dan tidak untuk dipinjam atau dibawa keluar dari ruangan tersebut. Lain halnya dengan koleksi standar yang bisa diakses langsung oleh pengguna dan bisa dipinjam melalui layanan sirkulasi. Kemudian ada juga layanan koleksi terbitan berseri seperti majalah, surat kabar dan jurnaljurnal penelitian yang juga bisa diakses langsung oleh pengguna karena menggunakan sistem layanan terbuka. Akan tetapi, layanan koleksi 
terbitan berseri ini juga tidak bisa dipinjamkan keluar oleh pengguna, hanya bisa dibaca dan dipergunakan di dalam gedung Perpustakaan USU saja.

Menurut Prastowo (2012, 83), ada empat aspek dalam penataan ruangan perpustakaan yang harus diperhatikan yaitu fungsional, psikologis pengguna, estetika dan keamanan bahan pustaka. Perpustakaan USU merancang tata ruangnya dan memperhatikan penempatan sarana dan prasarana untuk mengakomodasi semua koleksi dan layanan yang tersedia. Salah satu aspek yang diperhatikan adalah aspek keamanan, baik itu keamanan pengguna ketika berada di dalam perpustakaan maupun keamanan koleksi perpustakaan. Oleh karena itu, Perpustakaan USU merancang tata letak sarana dan prasarana sesuai dengan desain gedung dan luas ruangan yang ada untuk mengakomodasi semua koleksi dan layanan yang tersedia.

Begitu banyak pertimbangan yang diperhatikan untuk menentukan tata letak sarana dan prasarana yang sesuai dengan desain gedung dan luas ruangan yang ada untuk mengakomodasi semua koleksi dan layanan yang tersedia. Keberadaan sarana dan prasana, baik kualitas maupun kuantitasnya, juga tentunya telah diperhitungkan secara matang sehingga tercipta kesesuaian. Pengelolaan sarana dan prasarana Perpustakaan USU diatur dalam Rencana Kerja Anggaran Tahunan Perpustakaan USU.

Dengan mempertimbangkan semua aspek yang telah disebutkan di atas, maka akhirnya diperoleh gambaran penataan sarana dan prasarana di Perpustakaan USU sesuai dengan desain gedungnya. Pertama, Perpustakaan USU menyediakan loker yang ada di lantai 2 gedung Perpustakaan USU bagi pengguna yang akan masuk ke dalam ruangan perpustakaan. Keberadaan loker ini dimaksudkan sebagai tempat penyimpanan tas dan barang pengguna ketika mereka akan masuk ke ruangan perpustakaan karena pengguna tidak diizinkan membawa tas, jaket, makanan maupun minuman ke dalam ruangan perpustakaan sehingga harus dititipkan di loker. Kemudian, setelah menitipkan tas dan barangnya, pengguna dapat memulai penelusuran informasi yang dibutuhkan melalui fasilitas OPAC yang tersedia di semua lantai gedung Perpustakaan USU. Untuk koleksi standar, pengguna dapat mengakses langsung ke rak karena Perpustakaan USU menganut sistem layanan terbuka yang memberikan akses kepada pengguna untuk memilih dan mengambil langsung koleksi yang diinginkannya.

Perpustakaan USU juga menyediakan meja dan kursi baca untuk pengguna di depan jajaran rak buku. Penataannya diatur sedemikian rupa sesuai dengan desain gedung dan luas ruangan yang ada. Antara rak buku dan juga antara meja diberikan jarak yang cukup untuk mobilisasi pengguna di sekitar rak dan meja tersebut. Pengawasan terhadap aktivitas pengguna di meja baca juga perlu diperhatikan oleh pegawai. Hal ini dikarenakan tidak menutup kemungkinan pengguna melakukan pengrusakan koleksi ketika berada di area meja baca. Maka, perlu juga dilakukan pengawasan di area ini. Oleh karena itu penempatan meja baca juga merupakan langkah antisipasi yang perlu dipertimbangkan oleh perpustakaan ketika mendesain tata letak perabotannya. Untuk meja baca, Perpustakaan 
USU tidak lagi menggunakan sekat antar meja bacanya karena berdasarkan pengalaman yang terjadi, vandalisme justru dilakukan pengguna ketika berada di perpustakaan dengan memanfaatkan sekat-sekat yang ada pada meja baca tersebut. Oleh karena itu, Perpustakaan USU memutuskan untuk memotong atau menghilangkan semua sekat-sekat yang ada pada meja bacanya.

Jadi, berdasarkan pengalaman sebelumnya keberadaan meja baca yang bersekat menjadi akses bagi pengguna yang nakal untuk melakukan tindakan vandalisme. Hal ini kemudian yang mendorong pihak manajemen Perpustakaan USU untuk menghilangkan semua sekat pembatas yang ada di meja baca pengguna. Dengan tujuan, selain untuk mencegah vandalisme juga cara untuk membangun kemandirian mahasiswa dalam bertingkah laku di perpustakaan.

Sementara itu, untuk raknya, Perpustakaan USU menggunakan rak buku model dua muka agar menghemat space atau ruang yang ada karena jumlah koleksi yang dimiliki lebih dari 500.000 eksemplar. Penataan rak yang dilakukan secara lulus sejajar tersebut juga dimaksudkan untuk memudahkan pegawai mengawasi keamanan koleksi secara langsung sekaligus memantau aktivitas pengguna di sekitar rak buku.

Berbicara mengenai keamanan koleksi dari adanya indikasi tindakan vandalisme dan penyalahgunaan koleksi lainnya yang mungkin dilakukan pengguna, Perpustakaan USU mengantisipasinya dengan memberikan pengawasan koleksi kepada pegawai bagian shelving. Setiap pegawai di bagian shelving atau penataan bahan pustaka ke rak ini bertanggung jawab atas 5 rak buku. Dengan adanya pembagian tugas dan tanggung jawab atas rak buku dan koleksinya, maka beban tugas pegawai di bagian shelving menjadi lebih mudah untuk dikoordinasikan. Hal ini juga tentunya dipertimbangkan agar lebih mudah untuk mengawasi keamanan koleksi secara langsung dan juga sekaligus memantau aktivitas pengguna disekitar rak buku.

Di samping memperhatikan penataan rak buku dan juga meja baca, Perpustakaan USU juga mempertimbangkan keberadaan alat pengamanan di dalam maupun di luar gedung perpustakaan. Ini dilakukan untuk mengamankan koleksi dari ancaman vandalisme dan segala bentuk penyalahgunaan koleksi lainnya. Adapun alat pengamanan yang digunakan meliputi pemasangan pita magnetic di semua koleksi, penggunaan cctv, cermin dan juga magnet detector.

Pita magnetik digunakan sebagai tanda inventaris koleksi milik perpustakaan sehingga ketika pengguna membawa keluar koleksi harus melalui prosedur peminjaman di layanan sirkulasi. Keberadaan pita magnetik juga harus dilengkapi dengan magnet detector yang berfungsi sebagai alat pendeteksi sensor dari pita magnetik yang ada di dalam buku perpustakaan. Pita magnetik dan magnet detector merupakan alat pengamanan yang digunakan untuk mencegah dan mengantisipasi segala bentuk penyalahgunaan koleksi terutama pencurian terhadap koleksi perpustakaan.

Kemudian, pemasangan sistem keamanan elektronik seperti penggunaan kamera pengintai (CCTV) juga dilakukan oleh perpustakaan untuk memantau kegiatan pengguna di dalam 
perpustakaan. Perpustakaan USU menggunakan 22 unit CCTV di dalam maupun di luar gedung, termasuk di areal parkir perpustakaan. Dengan adanya CCTV, perpustakaan akan lebih mudah untuk mengontrol dan mengawasi aktivitas yang terjadi di lingkungan Perpustakaan USU.

Selain menggunakan CCTV sebagai alat pengamanan, Perpustakaan USU juga menggunakan kaca besar (cermin cembung) untuk memantau aktivitas di sekitar rak buku. Penempatan cermin cembung ini bersisian dengan CCTV dan juga kaunter atau meja tugas pegawai sehingga memudahkan pegawai untuk mengawasi aktivitas pengguna di sekitar rak dari meja tugasnya. Penempatan cermin cembung ini tegak lurus antara jajaran jendela perpustakaan dengan meja tugas pegawai. Hal ini dimaksudkan untuk mencegah pencurian buku dengan cara melempar buku perpustakaan melalui jendela yang terbuka ke luar gedung perpustakaan. Di samping mengandalkan pengawasan pegawai melalui pantauan cermin cembung dan juga CCTV, Perpustakaan USU mengantisipasi ancaman pencurian koleksi melalui jendela yang terbuka dengan mengubah taman di sekitar gedung perpustakaan menjadi area diskusi yang dilengkapi dengan meja dan kursi untuk pengguna perpustakaan. Kemudian, keberadaan satpam di beberapa titik di dalam maupun di luar gedung perpustakaan juga merupakan upaya yang dilakukan untuk mengantisipasi segala bentuk kejahatan dan penyalahgunaan di Perpustakaan USU. Keberadaan sarana dan prasarana di Perpustakaan USU diupayakan semaksimal mungkin dapat menciptakan pelayanan yang optimal sehingga memberikan kepuasan kepada pengguna.

\section{Aspek Layanan}

Perpustakaan USU terus berupaya melakukan peningkatan kualitas layanan dan fasilitas perpustakaan untuk memuaskan penggunanya. Bila pengguna sudah merasa puas dengan layanan yang diberikan oleh perpustakaan maka kemungkinan pengguna untuk melakukan vandalisme juga bisa diminimalisir. Hal ini dikarenakan salah satu penyebab terjadinya vandalisme di perpustakaan sebagaimana yang dikatakan oleh Daryono (2010) adalah kekecewaan pengguna terhadap layanan perpustakaan.

Visi Perpustakaan USU untuk "Menjadi suatu perpustakaan perguruan tinggi terkemuka dalam pelayanan terhadap sivitas akademikanya" mendorong Perpustakaan USU untuk selalu meningkatkan kualitas pelayanannya. Hal ini dapat dilihat dari predikat yang disandang oleh Perpustakaan USU beberapa tahun belakangan ini yang memiliki nilai akreditasi A menunjukkan bahwa kualitas pelayanan Perpustakaan USU masih sangat baik.

Salah satu cara yang dilakukan Perpustakaan USU untuk mempertahankan kualitas pelayanan yang baik adalah dengan menyediakan sumber informasi yang memadai kepada penggunanya dengan memberikan akses sebebas-bebasnya. Dari sisi layanan, Perpustakaan USU menyediakan berbagai jenis layanan untuk memenuhi kebutuhan informasi pengguna, di antaranya layanan koleksi standar, layanan koleksi referensi, layanan koleksi serial, layanan koleksi pinjam 
singkat (KPS) dan sebagainya. Dari berbagai jenis layanan yang disediakan tersebut, layanan koleksi standar merupakan layanan yang paling rentan terhadap masalah vandalisme karena sistem layanannya terbuka sehingga pengguna dapat mengakses langsung koleksi ke dalam rak. Dengan menganut sistem layanan terbuka maka peluang terjadinya vandalisme cukup besar terjadi di layanan koleksi standar ini.

Layanan koleksi standar atau koleksi umum yang menggunakan sistem terbuka, dimana pengguna memiliki akses langsung terhadap koleksi merupakan layanan yang paling sering mengalami tindakan vandalisme oleh pengguna. Hal ini disebabkan karena pengguna tidak dibatasi aksesnya untuk menelusur atau menemukan informasi yang dibutuhkan dari koleksi perpustakaan sehingga pengguna berinteraksi langsung dengan koleksi perpustakaan. Banyaknya jumlah pengguna dan jumlah koleksi tidak sebanding dengan jumlah pegawai atau staf perpustakaan yang bertugas di lapangan. Hal ini juga yang kemudian menyulitkan perpustakaan untuk mengontrol dan mengawasi aktivitas pengguna ketika berada di dalam perpustakaan.

Layanan dengan sistem terbuka rentan dengan ancaman penyalahgunaan koleksi yaitu vandalisme. Hal ini sebagaimana yang diungkapkan oleh Sri Hartati (2007), bahwa perpustakaan yang menganut sistem layanan terbuka akan membuka peluang bagi pemakai untuk menyalahgunakan koleksi. Oleh karena itu, kesiapan perpustakaan dalam menjalankan operasional layanannya sangat diperlukan agar ketika layanan tersebut dimanfaatkan oleh pengguna tidak menjadi 'ladang' bagi pengguna yang nakal untuk melakukan vandalisme yang jelas akan merugikan banyak pihak, khususnya perpustakaan itu sendiri. Walaupun sudah ada media pengamanan berupa pita magnetic, CCTV dan juga cermin cembung, keberadaan pegawai di sekitar rak koleksi juga dibutuhkan untuk memantau aktivitas pengguna dan juga membantu pengguna dalam menemukan informasi yang dibutuhkannya.

Di samping mengawasi aktivitas pengguna, pegawai di bagian shelving atau penataan koleksi perpustakaan juga bertanggung jawab untuk menata kembali koleksi yang digunakan oleh pengguna ke dalam rak sehingga apabila pengguna membutuhkan koleksi tersebut tidak kesulitan untuk menemukannya. Dalam hal penataan bahan pustaka, setiap pegawai bertanggung jawab atas 5 rak buku sehingga beban tugas penataan dan juga pengawasan koleksi di layanan koleksi standar ini lebih mudah untuk dikoordinasikan. Tingginya tingkat penggunaan koleksi perpustakaan oleh pengguna, sangat bergantung kepada aktivitas perkuliahan. Bila memasuki masa-masa ujian, maka aktivitas pengguna ke perpustakaan meningkat tajam bila dibandingkan hari biasanya. Ini juga merupakan dari upaya Perpustakaan USU untuk memberikan pelayanan yang maksimal kepada pengguna dalam memenuhi kebutuhan informasinya.

Mobilitas pegawai bagian shelving yang selalu berkeliling dan memantau pengguna ketika berada di dalam perpustakaan merupakan salah satu cara yang digunakan perpustakaan untuk mengatasi vandalisme. Karena dengan melihat lalu lalang pegawai di sekitar rak buku dan juga meja baca, membuat pengguna takut untuk 
melakukan vandalisme. Hal ini tentunya membuat pengguna berpikir ketika ada niat dalam dirinya untuk merobek ataupun merusak suatu bahan pustaka untuk kepentingannya sendiri. Perasaan takut ketahuan oleh pegawai ketika akan melakukan tindakan vandalisme, tentunya akan mendorong si pengguna tersebut untuk tidak jadi melakukan vandalisme karena ada pegawai yang mungkin akan melihatnya.

Sama halnya dengan pegawai di bagian penataan koleksi mengawasi keamanan koleksi dari tangan-tangan pengguna yang tidak bertanggung jawab, pegawai di bagian sirkulasi juga memantau dan mengawasi pengguna ketika akan meninggalkan gedung Perpustakaan USU. Di samping itu juga, mereka mengecek keutuhan koleksi ketika dikembalikan oleh mahasiswa. Pegawai di bagian layanan sirkulasi akan memantau dan mengawasi pengguna ketika akan meninggalkan gedung Perpustakaan USU. Oleh karena itu, guna memudahkan tugas pengawasan ini, pihak manajemen memutuskan utnuk menempatkan magnet detector di pintu keluar layanan sirkulasi sehingga ketika pengguna membawa koleksi perpustakaan tanpa melakukan transaksi peminjaman maka akan diketahui, mengingat di dalam koleksi perpustakaan, terutama koleksi buku, sudah diberikan pita magnetic. Seperti yang sudah disampaikan sebelumnya bahwa penggunaan pita magnetic dan magnet detector ini dimaksudkan sebagai salah satu strategi perpustakaan untuk mengantisipasi segala bentuk penyalahgunaan koleksi, terutama pencurian koleksi ataupun membawa lembaranlembaran koleksi yang dirobek keluar dari Perpustakaan USU. Hal ini bisa diketahui karena pita magnetic yang terdapat di dalam koleksi perpustakaan yang akan terdeteksi oleh magnet detector ketika pengguna keluar layanan sirkulasi dengan membawa koleksi tanpa melakukan transaksi peminjaman. Pengguna tidak mengetahui tepatnya di mana pita magnet tersebut diletakkan di dalam suatu koleksi sehingga ada kemungkinan akan ketahuan pegawai apabila mereka membawa koleksi keluar tanpa transaksi peminjaman.

Untuk dapat melakukan transaksi peminjaman, maka pengguna harus terdaftar sebagai anggota Perpustakaan USU. Adapun anggota yang dapat melakukan transaksi peminjaman adalah anggota dari kalangan civitas akademika USU yang terdiri dari mahasiswa, dosen dan juga staf atau pegawai di lingkungan USU. Sedangkan anggota di luar civitas akademika USU yang terdaftar sebagai anggota tamu Perpustakaan USU hanya dapat memanfaatkan fasilitas dan layanan yang tersedia tanpa dapat melakukan transaksi peminjaman. Hal ini dilakukan sebagai upaya Perpustakaan USU untuk mengamankan koleksinya karena ada kekhawatiran kalau koleksi tidak akan kembali apabila anggota tamu diberikan izin untuk melakukan transaksi peminjaman dan membawa pulang koleksi perpustakaan. Oleh karena itu, untuk mengatasi permasalahan manakala anggota tamu membutuhkan informasi dari suatu koleksi, Perpustakaan USU menyediakan layanan jasa fotocopy yang ada di lantai 3 gedung utama Perpustakaan USU.

Ketika pengguna melakukan transaksi peminjaman di layanan sirkulasi maka pegawai bagian peminjaman akan melakukan pemeriksaan 
fisik terhadap koleksi yang ingin dipinjam oleh pengguna. Hal ini dimaksudkan untuk memfilter koleksi yang rusak agar tidak keluar dari Perpustakaan USU. Apabila ditemukan suatu koleksi itu rusak ketika akan dipinjam oleh pengguna, maka petugas akan menahan buku tersebut dan tidak melakukan proses peminjaman. Ini dilakukan guna mencegah kerusakan yang lebih parah manakala koleksi yang rusak tersebut dipinjamkan kepada pengguna untuk dibawa pulang. Koleksi yang memiliki kerusakan tersebut nantinya akan diteruskan ke bagian layanan perawatan koleksi untuk mendapatkan perbaikan sehingga dapat kembali digunakan oleh pengguna.

Ketika melakukan transaksi peminjaman, pengguna harus menunjukkan Kartu Tanda Anggota (KTA) Perpustakaan USU. Pegawai yang bertugas melakukan transaksi peminjaman akan melakukan pengecekan identitas ke dalam sistem Perpustakaan USU dan mencocokkan wajah pengguna dengan photo yang tertera di KTA. Hal ini dilakukan guna mencegah penyalahgunaan KTA oleh pengguna yang tidak bertanggung jawab. Namun tidak dipungkiri terkadang masih saja terjadi penggunaan KTA yang bukan milik si pengguna oleh orang lain. Sedapat mungkin pegawai berusaha mencegah hal tersebut terjadi. Akan tetapi, karena beberapa faktor, hal seperti ini bisa saja terjadi. Misalnya, karena photo yang tertera di KTA sudah buram atau tidak jelas lagi, banyaknya antrian pengguna yang ingin meminjam koleksi perpustakaan memaksa pegawai untuk melakukan transaksi secara cepat sehingga tidak lagi fokus untuk melakukan pengecekan identitas pengguna, dan juga karena transaksi peminjaman si pengguna sudah penuh sementara dia membutuhkan suatu koleksi maka menggunakan KTA milik temannya untuk melakukan transaksi peminjaman. Hal lain yang melatarbelakangi penggunaan KTA milik orang lain adalah pengguna kehilangan KTA nya dan belum sempat mengurus penggantiannya. Maka untuk mencegah penyalahgunaan KTA yang hilang tersebut, Perpustakaan USU menghimbau kepada pengguna yang kehilangan KTA agar segera melaporkan masalah KTA yang hilang tersebut kepada pegawai di bagian sirkulasi untuk dilakukan pemblokiran sementara menunggu penggantian KTA nya.

Begitu pula sebaliknya, ketika pengguna mengembalikan koleksi ke Perpustakaan USU maka pegawai layanan sirkulasi bagian pengembalian juga akan melakukan pemeriksaan fisik terhadap koleksi yang dikembalikan. Karena sebelumnya Perpustakaan USU sudah mencegah koleksi yang rusak dipinjam oleh pengguna, maka akan lebih mudah memproses koleksi yang dikembalikan dalam keadaan rusak oleh pengguna. Perpustakaan USU mempunyai kebijakan terkait masalah kerusakan buku yang dilakukan oleh pengguna. Apabila kerusakan yang diakibatkan perlakuan pengguna masih tergolong ringan, maka Perpustakaan USU akan menerimanya dan hanya akan memberikan peringatan kepada pengguna berupa teguran agar lebih berhati-hati lagi dalam menggunakan koleksi perpustakaan. Sementara itu, untuk kerusakan koleksi yang tergolong sedang dan rusak parah, maka akan diberlakukan peringatan yang diikuti dengan surat perjanjian yang menyatakan pengguna tidak akan mengulangi perbuatannya dan memberikan ganti rugi sesuai ketentuan yang 
berlaku. Adapun ketentuan penggantian koleksi yang rusak yang berlaku di Perpustakaan USU adalah mengganti dengan koleksi yang sama sebanyak 1 eksemplar original (buku asli), atau 3 eksemplar hasil fotocopy apabila koleksi tersebut tidak lagi ditemukan di pasaran. Ketentuan ini juga berlaku untuk koleksi yang dihilangkan oleh pengguna. Khusus untuk koleksi terbitan luar negeri yang cenderung susah didapatkan di pasaran, Perpustakaan USU menerima penggantian koleksi dengan hasil fotocopy sebanyak 3 eksemplar. Hal ini dilakukan karena Perpustakaan USU pada dasarnya tidak ingin menyulitkan pengguna dan juga bagi Perpustakaan USU yang penting adalah koleksinya kembali dan bisa digunakan oleh pengguna.

Selain layanan koleksi standar yang bisa dipinjam oleh pengguna, jenis layanan lain yang memungkinkan pengguna untuk melakukan transaksi peminjaman adalah layanan Koleksi Pinjam Singkat atau dikenal dengan layanan KPS. Akan tetapi yang membedakan layanan KPS ini dengan layanan koleksi standar adalah sistem layanannya yang tertutup dan juga masa waktu peminjamannya yang sangat singkat yaitu hanya 2 hari saja. Karena sistem layanan yang tertutup, pengguna tidak dapat mengakses langsung koleksi yang diinginkan langsung ke rak. Pengguna dapat memanfaatkan layanan OPAC yang tersedia di depan layanan KPS dan mencatat nomor panggilnya untuk kemudian diserahkan kepada pegawai yang bertugas. Pegawai akan mencari koleksi yang diinginkan pengguna sesuai dengan nomor panggil yang diberikan ke dalam rak dan apabila koleksi tersebut tersedia maka pegawai akan menunjukkannya kepada pengguna. Apabila koleksi tersebut sesuai dengan kebutuhan pengguna dan pengguna ingin meminjamnya makan petugas akan melakukan transaksi peminjaman. Adapun prosedur peminjaman di layanan KPS sama dengan prosedur peminjaman di layanan sirkulasi, hanya lama waktu peminjaman dan batas jumlah koleksi yang dapat dipinjam yang berbeda. Kalau di layanan sirkulasi untuk koleksi standar, sesuai dengan ketentuan yang berlaku, untuk mahasiswa USU dapat meminjam maksimal 5 judul selama 2 minggu dengan 1x masa perpanjangan, sementara itu untuk dosen, staf dan peneliti dapat meminjam maksimal 10 judul selama 2 minggu dengan $2 \mathrm{x}$ perpanjangan. Sedangkan di layanan KPS, mahasiswa USU dapat meminjam maksimal 2 judul selama 2 hari dengan 1x masa perpanjangan, sementara itu untuk dosen, staf dan peneliti dapat meminjam maksimal 2 judul selama 2 hari dengan $2 \mathrm{x}$ perpanjangan. Singkatnya masa pinjam di layanan KPS dikarena koleksi yang tersedia hanya ada 1 eksemplar untuk 1 judul. Oleh sebab itu, Perpustakaan USU membuat kebijakan masa pinjam yang singkat untuk koleksi di layanan KPS ini.

Pegawai yang bertugas di layanan KPS ini juga melakukan pemeriksaan fisik terhadap koleksi baik ketika akan dipinjamkan maupun saat dikembalikan oleh pengguna. Apabila ditemukan kerusakan ketika pengembalian dan/atau koleksi hilang, maka diberlakukan ketentuan yang sama dengan ketentuan yang ada di layanan sirkulasi, yaitu mengganti dengan koleksi yang sama sebanyak 1 eksemplar original (buku asli), atau 3 eksemplar hasil fotocopy apabila koleksi tersebut 
tidak lagi ditemukan di pasaran dan/atau merupakan koleksi terbitan luar negeri yang susah didapatkan.

Koleksi di layanan KPS sangat jarang ditemukan dalam keadaan rusak karena setiap transaksi, baik peminjaman maupun pengembalian, pegawai kerap melakukan pengecekan terhadap fisik koleksi. Dengan diberlakukannya sistem layanan tertutup pada layanan KPS ini, membantu pegawai lebih mudah untuk melakukan kontrol atau pengawasan terhadap keutuhan koleksinya dan sedapat mungkin kerusakan akibat vandalisme bisa diminimalisir. Karena menganut sistem layanan tertutup, maka kemungkinan terjadinya vandalisme di layanan KPS sangat kecil terjadi karena pegawai langsung berinteraksi dengan pengguna dan juga koleksinya. Pegawai menjadi mediator yang menghubungkan antar pengguna dengan koleksi yang diinginkannya. Oleh karena itu, kemungkinan pengguna untuk melakukan vandalisme terhadap koleksi di layanan KPS ini hampir tidak ada sama sekali. Pegawai kerap melakukan pemeriksaan terhadap koleksi baik ketika akan dipinjam oleh mahasiswa maupun ketika koleksi tersebut dikembalikan oleh mahasiswa.

Walaupun kemungkinan untuk menjadi objek dari tindakan vandalisme sangat kecil, layanan KPS juga terkadang kehilangan koleksinya akibat kelalaian pengguna. Pengguna yang menghilangkan koleksi dengan alasan apapun akan dikenakan sanksi atau denda penggantian koleksi sesuai dengan ketentuan yang berlaku yaitu kalau untuk buku yang hilang, harus diganti, kalau gantinya original atau sebanyak 1 eksemplar, atau fotocopy sebanyak 3 eksemplar. Dengan catatan, boleh fotocopy kalau buku aslinya tidak ada lagi di pasaran, atau bukunya terlalu mahal harganya, misal buku-buku terbitan luar negeri.

Selain masalah yang timbul akibat kelalaian pengguna menjaga koleksi KPS ketika meminjam koleksi sehingga koleksi tersebut hilang, masalah lain yang sering ditemukan di layanan KPS ini adalah penggunaan KTA milik orang lain. Adapun tindakan yang diambil oleh pegawai di bagian layanan KPS Perpustakaan USU atas penggunaan KTA milik orang lain oleh pengguna adalah tidak akan memberikan izin peminjaman karena munculnya kekhawatiran akan penyalahgunaan KTA tersebut oleh orang yang tidak bertanggung jawab sehingga transaksi peminjaman tidak akan dilakukan oleh pegawai apabila bukan si pemegang atau pemilik asli KTA tersebut yang melakukan peminjaman di kaunter layanan KPS Ini dilakukan untuk menjamin hak dan kewajiban pengguna yang memiliki KTA Perpustakaan USU. Oleh karena itu, pengguna harus benarbenar menjaga KTAnya agar tidak hilang dan disalahgunakan oleh orang lain. Apabila KTA tersebut hilang maka kepada pengguna disarankan untuk melapor ke bagian layanan sirkulasi untuk pemblokiran penggunaan KTA tersebut dari segala transaksi peminjaman koleksi Perpustakaan USU.

Pentingnya menjaga KTA perlu kiranya dilakukan oleh pengguna Perpustakaan USU agar pada akhirnya tidak merugikan diri sendiri akibat kelalaian menjaga KTA tersebut. Apabila KTAnya hilang maka kepada pengguna disarankan untuk melapor ke bagian layanan 
sirkulasi untuk pemblokiran penggunaan KTA tersebut dari segala transaksi peminjaman koleksi Perpustakaan USU. Hal ini dilakukan untuk mengantisipasi tindakan penyalahgunaan KTA dengan memanfaatkan KTA milik orang lain yang hilang. Oleh karena itu, pengguna harus menjaga KTAnya dengan baik sehingga tidak disalahgunakan oleh orang lain.

Koleksi yang rusak perlu mendapatkan perawatan dan perbaikan agar dapat dimanfaatkan kembali oleh pengguna. Untuk menangani kerusakan koleksi akibat vandalisme diperlukan kerjasama dan koordinasi dari berbagai pihak. Upaya perbaikan dan perawatan koleksi ini merupakan kerjasama antara pegawai di bagian perawatan koleksi dengan pegawai yang bertugas di bagian sirkulasi maupun pegawai di bagian shelving. Ketika petugas melakukan shelving ataupun saat pengguna melakukan pengembalian koleksi di layanan sirkulasi, setiap buku atau koleksi perpustakaan yang ditemukan diperiksa. Apabila ditemukan kerusakan, baik kerusakan sampul maupun kehilangan lembaran halaman koleksi, maka koleksi tersebut akan dikirim ke bagian perawatan koleksi untuk dilakukan perbaikan.

Perpustakaan USU menyediakan layanan perawatan koleksi yang berada di lantai 4 gedung utama Perpustakaan USU. Pegawai layanan perawatan koleksi berkoordinasi dengan pegawai yang bertugas di layanan sirkulasi maupun di bagian shelving untuk mengumpulkan koleksikoleksi yang rusak agar segera mendapatkan perbaikan. Adapun jenis kerusakan yang biasanya ditemukan meliputi kerusakan sampul, kehilangan lembaran halaman koleksi, perobekan maupun punggung buku yang patah karena ditekan ketika pengguna menggunakannya. Keberadaan layanan perawatan koleksi ini sangat dibutuhkan untuk mengatasi dan memperbaiki koleksi-koleksi yang rusak tersebut, terutama kerusakan akibat aktivitas vandalisme yang dilakukan oleh pengguna. Upaya perbaikan yang dilakukan bertujuan untuk mengembalikan kandungan informasi yang dimiliki sehingga utuh dan dapat dimanfaatkan kembali oleh pengguna. Bila ada beberapa lembar halaman yang hilang, rusak atau robek, maka pegawai bagian perawatan koleksi akan mencari halaman yang hilang, rusak atau robek tersebut dari koleksi yang sama untuk kemudian difotocopy dan direkatkan kembali sehingga utuh lagi informasinya.

Perpustakaan USU juga memberikan akses kepada pengguna untuk meminta perbaikan langsung kepada pegawai di bagian layanan perawatan koleksi apabila koleksi tersebut memang sangat dibutuhkan dan tidak lagi koleksi yang sama tersedia di rak dalam keadaan baik. Apabila kerusakan koleksi tersebut tidak terlalu parah, maka pegawai akan segera melakukan perbaikan agar pengguna dapat membawanya ke layanan sirkulasi untuk melakukan transaksi peminjaman. Akan tetapi, apabila koleksi yang diinginkan pengguna tersebut memiliki kerusakan yang cukup parah dan membutuhkan waktu untuk perbaikannya, biasanya pegawai akan meminta waktu kepada pengguna untuk memperbaikinya dan setelah selesai diperbaiki maka pengguna dapat mengambilnya dan melakukan transaksi peminjaman di layanan sirkulasi.

Perpustakaan USU berusaha untuk memberikan pelayanan yang baik dan memuaskan 
kepada pengguna termasuk dalam menyediakan koleksi yang utuh dan tidak rusak untuk memenuhi kebutuhan informasi pengguna. Ini juga merupakan strategi yang dilakukan untuk mengatasi masalah vandalisme di Perpustakaan USU. Vandalisme tidak dapat dihilangkan atau dimusnahkan. Akan tetapi, vandalisme dapat diminimalisir dengan peningkatan kualitas layanan, kebutuhan pengguna terpenuhi baik dari sisi sumber daya atau resource yang dimiliki, bahan pustaka yang dimiliki, serta sistem yang terintegrasi dengan cepat. Apabila hal-hal tersebut dapat dipenuhi, maka vandalism tidak perlu terjadi di perpustakaan.

Dengan menyediakan koleksi yang bagus dan utuh, kemudian disertai dengan perbaikan sistem layanan yang berorientasi kepada kepentingan pengguna merupakan langkah yang diambil oleh Perpustakaan USU untuk menekan kerugian yang mungkin ditimbulkan akibat adanya aktivitas vandalisme oleh pengguna. Di samping itu, untuk mendukung pemanfaatan fasilitas dan layanan yang disediakan di perpustakaan secara maksimal, keberadaan layanan bimbingan pengguna juga memiliki peran penting. Karena sebagaimana yang telah diketahui bahwa kemampuan pengguna dalam memanfaatkan fasilitas dan layanan yang tersedia di perpustakaan tidaklah sama sehingga perlu diadakan layanan bimbingan pengguna yang tujuannya adalah untuk membantu pengguna memanfaatkan perpustakaan secara maksimal.

Pelayanan bimbingan pengguna mempunyai peranan sangat penting karena tidak semua pengguna perpustakaan tahu bagaimana cara pemanfaatan perpustakaan. Pelayanan ini sangat baik diberikan kepada pengguna perpustakaan yang sama sekali belum tahu bagaimana cara menggunakan perpustakaan yang sebenarnya . Menurut Sutarno (2006, 95-96), kegiatan bimbingan pengguna merupakan suatu kegiatan yang bermaksud memberikan panduan, penjelasan tentang pengguna perpustakaan kepada sekelompok pengguna baru perpustakaan.

Pelayanan bimbingan pengguna adalah kegiatan membimbing atau memberikan petunjuk kepada pengguna dan calon pengguna agar mampu memanfaatkan kemudahan dan pelayanan perpustakaan dengan efektif dan efisien. Pelayanan pengguna mempunyai peranan sangat penting karena tidak semua pengguna perpustakaan tahu bagaimana cara pemanfaatan perpustakaan. Pelayanan ini sangat baik diberikan kepada pengguna perpustakaan yang sama sekali belum tahu bagaimana cara menggunakan perpustakaan yang sebenarnya.

Menurut Widyawan (2012), bimbingan pengguna, dalam istilah Ilmu Perpustakaan dan Informasi disebut dengan Library Instruction, bibliographic instruction (BI), user education dan library orientation, berisi program bimbingan yang dirancang untuk mengajari pemustaka agar memperoleh informasi yang mereka perlukan dengan cepat dan efektif (Rosa, 2012). Bimbingan ini mencakup sistem perpustakaan dalam menyusun bahan pustaka, struktur literatur bidang ilmu tertentu, metodologi riset yang tepat untuk disiplin ilmu tersebut, dan sumber-sumber khusus serta sarana temu balik informasi seperti katalog, pelayanan indeks dan abstrak, pangkalan data bibliografis dan lain sebagainya. Bimbingan ini disiapkan untuk mereka agar mampu menggunakan informasi 
langsung dan seumur hidupnya secara efektif dengan mengajarkan konsep dan logika akses informasi serta evaluasi dan mendukung pengembangan informasi dengan berfikir kritis dan mandiri.

Pada awalnya, Perpustakaan USU mengadakan kegiatan bimbingan pengguna ini secara rutin dan terjadwal. Akan tetapi, dikarenakan kebiijakan rektorat yang tidak lagi mendukung secara financial, kegiatan bimbingan pengguna ini tidak lagi berjalan sebagaimana sebelumnya. Sekarang, kegiatan ini terbatas pada mahasiswa pascasarjana saja karena adanya permintaan dari pengelola program pascasarjana USU. Sedangkan untuk mahasiswa program S1 dan DIII, kegiatan bimbingan pengguna ini tidak lagi diakomodasi seperti sebelumnya. Maka ketika pengguna menemukan kesulitan dalam menemukan informasi ataupun dalam memanfaatkan layanan dan fasilitas yang disediakan oleh Perpustakaan USU, pengguna dapat meminta bantuan ke layanan referensi dan bantuan pengguna yang terdapat di lantai 3 gedung utama Perpustakaan USU.

Memang sangat disayangkan kegiatan bimbingan pengguna ini dipasifkan mengingat peran penting layanan bimbingan pengguna untuk membangun kesadaran pengguna. Keberadaan layanan bimbingan pengguna dibutuhkan untuk membentuk kemandirian pengguna dalam memanfaatkan layanan dan fasilitas yang disediakan oleh Perpustakaan USU. Dengan adanya kemandirian tersebut, pengguna akan memanfaatkan layanan dan fasilitas yang disediakan dengan cerdas dan bertanggung jawab. Pada akhirnya, bila pengguna sudah cerdas dan memiliki rasa tanggung jawab dalam memanfaatkan koleksi perpustakaan, tentunya halhal seperti vandalisme tidak akan lagi ada di perpustakaan.

Pihak manajemen yang menjalankan operasional layanan perpustakaan harus memikirkan langkah-langkah yang strategis untuk menciptakan situasi dan kondisi yang nyaman dan aman dalam memberikan pelayanan kepada pengguna. Perlunya perencanaan yang cermat dan strategis untuk menunjang pelaksanaan kerja yang kondusif dan bersahabat guna meningkatkan efektivitas kerja dan juga meningkatkan kualitas pelayanan kepada pengguna akan mendorong pencapaian arah dan tujuan perpustakaan sebagaimana yang tertuang dalam visi dan misi perpustakaan. Di samping itu, perencanaan manajemen yang berorientasi kepada kepedulian pengguna akan menekan angka kerusakan koleksi maupun kejahatan di lingkungan perpustakaan. Oleh karena itu, kiranya pihak manajemen perpustakaan membuat perencanaan di segala aspek dengan mempertimbangkan semua faktor pendukung maupun faktor penghambat agar dapat terus meningkatkan kualitas pelayanannya dalam upaya memenuhi kebutuhan pengguna. Di samping keberadaan sumber daya koleksi dan sistem yang menunjang, juga dibutuhkan anggaran dari universitas, di antaranya untuk membayar gaji pegawai, termasuk pengadaan bahan pustaka dan membangun sistem perpustakaan yang bagus. Kalau itu semua sudah terpenuhi, tentunya kinerja SDM pasti akan bagus dan professional. Pada akhirnya, dengan kinerja SDM yang professional maka akan tercipta 
dengan sendirinya manajemen perpustakaan yang baik untuk melayani pengguna.

Manajemen perpustakaan dapat berjalan dengan baik apabila dilandasi rasa kepedulian yang tinggi terhadap kepentingan pengguna. Dengan demikian, manajemen akan berusaha merancang sistem perpustakaan yang bagus dan memuaskan di segala aspek yang meliputi SDM, anggaran, sarana prasarana maupun layanan yang disediakan oleh perpustakaan. Pada akhirnya, bila perpustakaan sudah menyediakan sumber daya atau resources yang sesuai dengan kebutuhan pengguna maka dengan sendirinya segala bentuk penyalahgunaan koleksi termasuk vandalisme akan hilang dengan sendirinya. Dari uraian hasil dan pembahasan yang sudah dijabarkan di atas, maka dapat digambarkan strategi manajemen Perpustakaan USU dalam menghadapi ancaman vandalisme dalam model pada gambar 1 .

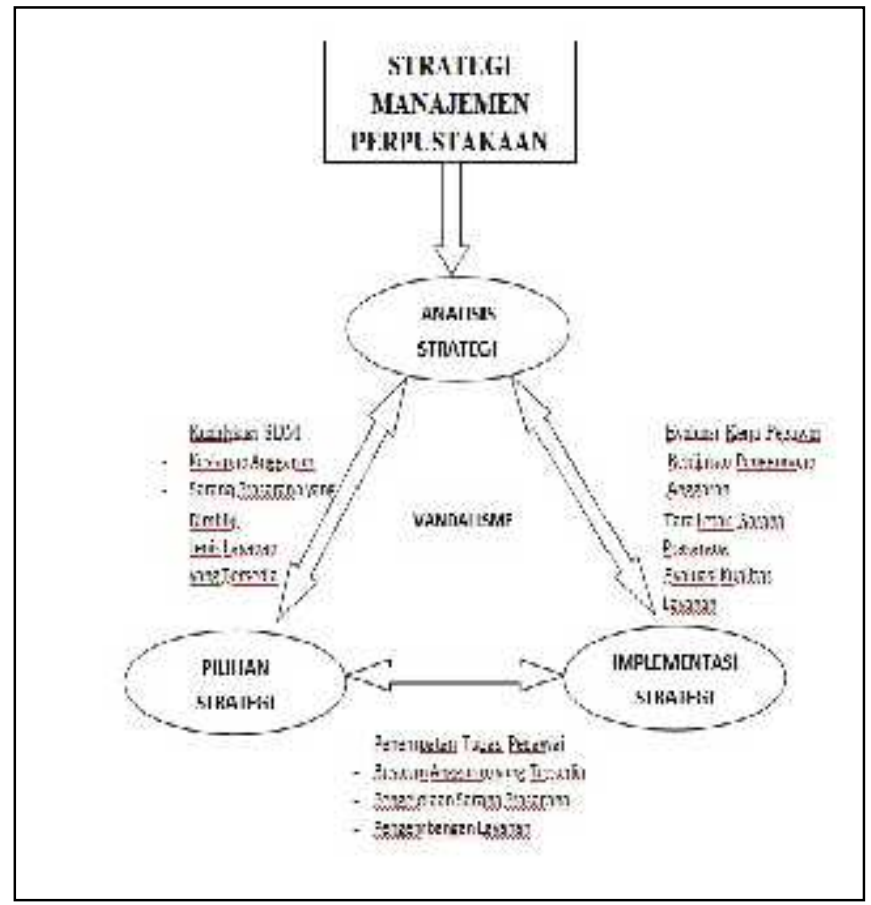

Gambar 1. Model Strategi Perpustakaan dalam Menghadapi Vandalisme

\section{SIMPULAN}

1. Dari aspek sumber daya manusia, Perpustakaan USU mempekerjakan lulusan ilmu perpustakaan dan informasi untuk mendukung ketersediaan SDM yang bermutu sehingga dapat mendukung kinerja perpustakaan. Berdasarkan latar belakang pendidikan dan bidang keahlian diatur penempatan posisi tugas pegawai sehingga dapat memberikan pelayanan yang maksimal kepada pengguna. Penempatan meja tugas pegawai juga dirancang agar dapat menjangkau pengawasan di sekitar rak dan meja baca yang digunakan oleh pengguna perpustakaan. Di samping itu, penempatan sejumlah personil keamanan (satpam) di beberapa titik, baik di dalam maupun di luar gedung, juga dilakukan oleh Perpustakaan USU untuk menjaga keamanan koleksi perpustakaan dari segala tindak penyalahgunaan koleksi termasuk vandalisme.

2. Dari aspek anggaran, Perpustakaan USU membuat perencanaan anggaran untuk menyediakan fasilitas dan layanan yang memadai untuk memenuhi kebutuhan pengguna termasuk pengadaan koleksi, sarana prasarana pendukung serta sistem yang menunjang kegiatan pelayanan perpustakaan. Kesiapan anggaran dibutuhkan untuk meningkatkan kualitas layanan perpustakaan. Di samping itu, Perpustakaan USU juga mengalokasikan anggaran untuk perbaikan koleksi melalui keberadaan layanan perawatan koleksi. 
3. Dari aspek sarana prasarana, Perpustakaan USU merancang desain gedung dan ruangan yang unik didukung dengan sistem keamanan (penggunaan CCTV, pita magnetic, magnet detector, dan cermin cembung). Tata letak sarana prasarana juga diatur sedemikian rupa untuk menunjang kinerja pegawai dan memberikan kemudahan, kenyamanan serta rasa aman untuk pengguna perpustakaan. Penataan sarana dan prasaran dilakukan semaksimal mungkin untuk mendukung pelayanan yang optimal dan memininalisir kemungkinan terjadinya vandalisme di Perpustakaan USU.

4. Dari aspek layanan, Perpustakaan USU menyediakan berbagai jenis layanan untuk mengakomodasi kebutuhan pengguna. Perpustakaan USU memberikan akses kepada pengguna melalui sistem layanan terbuka untuk koleksi standar sehingga memberikan pilihan kepada pengguna untuk menemukan informasi sesuai dengan kebutuhannya, kemudahan transaksi peminjaman, pengembalian dan perpanjangan tanpa prosedur keanggotaan yang rumit, menyediakan layanan jasa fotokopi dan juga fasilitas scanning (secara gratis) untuk pengguna yang membutuhkannya, mengadakan sistem layanan tertutup untuk layanan koleksi pinjam singkat (layanan KPS), menyediakan layanan perawatan koleksi di dalam gedung Perpustakaan USU guna memudahkan dan mempercepat proses perbaikan koleksi yang rusak, serta menyediakan layanan rujukan dan bantuan pengguna yang akan membantu pengguna untuk menemukan informasi sesuai dengan kebutuhannya dan juga mengarahkan pengguna agar dapat memanfaatkan semua fasilitas dan layanan yang disediakan oleh perpustakaan secara maksimal. Keberadaan berbagai jenis layanan tersebut ditujukan untuk memenuhi kebutuhan pengguna yang beragam sehingga dapat memberikan pilihan kepada pengguna dalam memanfaatkan fasilitas dan layanan yang disediakan oleh Perpustakaan USU. Dengan memberikan layanan yang maksimal maka kemungkinan terjadinya vandalisme dapat diminimalisir.

\section{DAFTAR PUSTAKA}

Azyumardi. (2004). Bukuku Kakiku. Jakarta: Gramedia Pustaka Utama.

Bryson, Jo. (1990). Effective Library and Information Centre Management. Brookfield: Gower Publishing Company.

Daryono. (2010). Faktor-Faktor Penyebab terjadinya Tindakan Vandalisme Koleksi Perpustakaan dan Upaya Pencegahannya. Media Pustakawan Vol.17 No.1, Juni.

Dureau, J.M \& Clements, D.W.G. (1990). Dasardasar Pelestarian dan Pengawetan Bahan Pustaka. Jakarta: Perpustakaan Nasional R.I.

Fatmawati, Endang. (2007). Vandalisme Perpustakaan. Media Informasi Vol.XVI No.1. Yogyakarta: Perpustakaan UGM. (2010). The Art of Library: Ikatan Esai Bergizi tentang Seni Mengelola Perpustakaan. Semarang: Badan Penerbit UNDIP.

Harian Suara Merdeka. (2007). Layanan Terbuka Perpustakaan, Peluang Penyalahgunaan Koleksi. Diakses dari http://www.suaramerdeka.com/harian/0706/ 07/ked06.htm pada tanggal 14 September 2013 pukul 14:00.

Lasa HS. (2005). Manajemen Perpustakaan. Yogyakarta: Gama Media.

Martoadmodjo, Karmidi. (1993). Pelestarian Bahan Pustaka. Jakarta: Universitas Terbuka. 
Obiagwu, Marcel C. (1992). Library Abuse in Academic Institutions: A Comparative Study. International Information and Library Review, Vol. 24 No. 4 (p.291-305).

Prastowo, Andi. (2012). Manajemen Perpustakaan Sekolah Profesional. Yogyakarta: DIVA Press.

Pusat Bahasa Departemen Pendidikan Nasional. (2003). Kamus Besar Bahasa Indonesia. Ed.3. Jakarta: Balai Pustaka.

Rahayuningsih, F. (2007). Vandalisme Di Perpustakaan. Genta Pustaka: Menuju Perspektif Baru Perpustakaan Vol. I Nomor 4. Semarang: Perpustakaan Unika Soegijapranata.

Sasmita, Mamat. (2007). Mimpi Kampung Buku di Bandung. Diakses dari www.bit.lipi.go.id/masyarakatliterasi/index.php/home/819 pada tanggal 22 November 2013 pukul 10:48.

Sulistyo-Basuki. (1991). Pengantar Ilmu Perpustakaan. Jakarta: Gramedia Pustaka Utama.

Sumardji, P. (1982). Pelayanan Perpustakaan; Tatakerja Pelayanan Sirkulasi (Melayani Peminjaman dan Pengembalian Buku) di Perpustakaan. Yogyakarta: Kanisius.

Sutarno, NS. (2006). Manajemen Perpustakaan. Jakarta: Sagung Seto.

Widyawan, Rosa. (2012). Pelayanan Referensi, Bimbingan Pemustaka, dan Literasi Informasi. Diakses dari http://irsreference.blogspot.com/2012/04/pelayananreferensi-bimbingan-pemustaka.html pada tanggal 23 Mei 2014 WIB

Zulkarnaen, Sani. (2007). Pemanfaatan Koleksi Buku Diakses pada tanggal 3 Juni 2010 pukul 12:00 WIB dari http://www.ziddu.com/download/23023151/ PemanfaatanKoleksiBuku.rtf.html 
